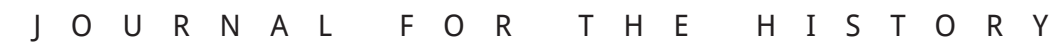

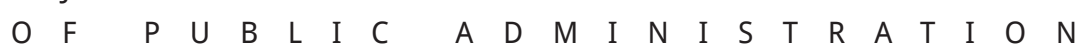

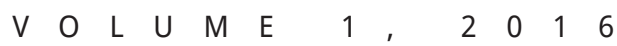

$\begin{array}{llllllllllllllll} & A & G & E & 1 & 5 & 5 & - & 1 & 7 & 2\end{array}$

D O I : $10.2478 /$ ADHI-2018-0009

\title{
Colonial Bureaucrats, Institutional Transplants, and Development in the 20th Century
}

VALENTIN SEIDLER ${ }^{1}$

\section{Introduction: Training, Transplants and Tailors}

From 1962 to 1971, Colin Baker, an Englishman born in 1929 in Suffolk, found himself in charge of a series of legal training courses in Nyasaland. The British protectorate in East Africa was on its way to becoming the independent state of Malawi in 1964. The aim of the training was to prepare African personnel for their duties in the higher civil service. Today, training local bureaucrats for duties in modern administrations is nothing new. It has been a core activity of development practitioners and international agencies since World War II. $^{2}$ In a wider context, the activities summed up under slocal capacity building a are often regarded as a development goal in itself or as an important factor ensuring ssustainable development $\iota^{3}$

This text introduces a research agenda in which well-trained local officers serve a second purpose - to successfully transplant foreign institutions (such as the law) into societies lacking them. There is a rich literature on colonial and postcolonial administration, state building and the failures therein. ${ }^{4}$ Seemingly unaffected by this literature, economists and development professionals have searched for better ways of delivering development. Since the 1990s institutions have taken a central role. Economists understand institutions as the rules of the game used in modern states. The legislative system, the judiciary or specific laws and regulations are examples for such institutions. ${ }^{5}$ Compared to the transfer of hard technology into developing countries, the transplant of rules is considered more complicated. Yet, it may be even more important. Development scholars regard good institutions (such as non-corrupt administrations or an efficient and independent judiciary) as a fundamental factor in promoting long-term economic growth. ${ }^{6}$ The problem of how such good institutions can be established is one of the big open questions in development economics today. No one has ever looked at the bureaucrats and individuals in charge of transplanting. Do they have the skills and the ability to customize foreign institutions so that they fit into the institutional context of the receiving society? ${ }^{7}$

Who are these bureaucrats and experts? Modern-day slocal capacity building ، does not necessarily create them. Training local bureaucrats merely enables them to fulfill functions in newly transplanted bodies of law. It does not create individuals who are capable of building customized, tailor-made institutional solutions in the first place. For the sake of my argument I will refer to them as stailors to distinguish them from experts and bureaucrats in charge of transplanting who lack the specific skills or the experience to create a customized institutional copy. 
Training local officials, as it is practiced today, will not necessarily create tailors. But it will promote the global dissemination of a relatively homogeneous body of standards in law and in governance. It is this dimension of capacity building that seems to be an integral part of international development efforts such as the Sustainable Development Goals propagated by the United Nations. ${ }^{8}$ These development efforts have been regarded as problematic by postcolonial scholars, among others. Western rules of the game in areas like international trade may put new players at a disadvantage either because of their intentional design or simply because new players have little experience or lack skilled experts. ${ }^{9}$ While this criticism is valuable, institutional transplants - in which the newly trained bureaucrats are supposed to work - suffer from a more fundamental problem. Because these institutions have not been adapted to the local context in the first place, they very often fail.

In many cases transplanted institutions consist of bodies of imported law which to some extent conflict with local practices. An example: Even a rather uncontroversial, imported institution such as the road code can create dead law or the illusion of reform without its intended benefits. ${ }^{10}$ What is the use of well-formulated road regulations if they are widely ignored? Take a taxi anywhere in Phnom Penh and you will realize that local and unwritten norms prevail over formal legal text. ${ }^{11}$ Contrary to what the Cambodian road code stipulates, the bigger vehicle takes the right-of-way, simply because it can cause more damage. ${ }^{12}$ In this sense transplants conflicting with local norms may result in a major irritation of the pre-existing order and even promote corruption. ${ }^{13}$

How can we get the transplanting process right? That is the problem which the research program presented here intends to investigate. We know from the few successful examples that the key to transplanting lies in the adaptation of the imported, foreign standard to the local context. ${ }^{14}$ This creates innovative, hybrid institutions which find more acceptance with local actors. Hybrids may not look like the best practice around, but they do function as intended in the environment for which they were created. ${ }^{15}$ At the same time hybrids counteract the emergence of a homogeneous body of international rules of governance which potentially discriminates late-comers. Think, for example, of a new Cambodian traffic law that would take into account the local norm of »bigger vehicle goes first «. ${ }^{16}$ Alas, such institutional adaptation requires individuals with very specific experience and training. The persons in charge of adaptation need to understand the local norms (»bigger vehicle goes first«) as well as the aim and the functions of the imported institution in the country of its origin. Careful balancing of which new elements can be imposed and which ones need to be adapted would be their main task - very much in the way a tailor customizes a suit to the individual needs of his customer. From today's point of view, these tailors may be local bureaucrats with a very good foreign education, or else expatriates with substantial localized knowledge of the receiving society.

Once we go back in history, we do find both types of experts employed as colonial officers in the British colonies in the mid-20th century. I will discuss British decolonization in more detail below. At this point it suffices to say that it was a period of intensified institutional reform and legal copying. Senior colonial officers held high positions in the newly created ministries and governmental agencies. Many of them stayed on after independence as advisors or as public servants in the service of the newly independent countries. Compared with the foreign experts and advisers of that time, they held very influential posts. ${ }^{17} \mathrm{Mr}$. Colin Baker in Nyasaland was one of them. In 1963 he was charged with training a dozen students, most of them in their mid-thirties, for their future role as lay magistrates. We know from his personnel record kept by the Colonial Office that Mr. Baker held a law degree from London. He had served in Nyasaland since 1954. He had passed a local language exam and had a good understanding of the challenges ahead for the civil service.

Lay magistrates or Justices of the Peace are a British institution which is still in use in many former colonies. They are judicial officers, civil servants of lower courts, who dispense justice or deal with legal administrative procedures. In Britain, lay magistrates need not have much if any knowledge of the substantive law or judicial procedures. They have professionally qualified Clerks of the Court to instruct them. In the Nyasaland of 1963, the first magistrates had no such luxury. There were no professional clerks to guide them - hence they had to learn both, the substantive law and the legal procedures at court. In England both these areas are covered by British law: the Penal Code and the Criminal Procedure Code, neither of which is straightforward or easy 
to understand (still less to apply) without being trained to do so. However, in Nyasaland in 1963, the need for trained personnel was tremendous and so was the political pressure to supply them. The organizers of the training courses were given six months. In this situation Mr. Baker did what many other officers did around that time in the British colonies - he improvised. He single-handedly devised two rough and easy manuals, one of the Penal Code and one of the Criminal Procedure Code. The manuals and their content were designed to fit the education and training level of the students. They came with guides, slips of colored paper which mapped out the routes of procedures at court. His students would later use them on the Bench unseen by the public. The result may have been a very simplified copy of the real thing. The British Penal Code and Criminal Procedure Code may not have been copied in all details. But we know today that these first lay magistrates in Malawi were, on the whole, successful. They secured public confidence in the law. If their decisions were reversed on appeal by a higher, professional court, they failed on procedural grounds rather than on grounds of reaching the wrong decision. ${ }^{18}$ From this perspective, the accomplishment of Mr. Baker was not necessarily the training of the local bureaucrats in itself but the adaptation of the training content, i.e. the institution to be copied, to the local conditions of Nyasaland shortly before its independence. In my argument presented here, this makes him a tailor.

While the episode above is an example of successful transplanting, the overall record of the British legacy in its former colonies is mixed. Botswana, for example, is regarded a success story in terms of institutions, while neighboring Lesotho is not. ${ }^{19}$ Can the availability of colonial officers with a very specific background and training explain at least parts of this variation? To explore this question, I constructed a digital dataset of personnel records of all senior officers in 46 British colonies between 1939 and 1966. The set contains over 14,000 officers, of whom roughly one quarter were not British. Not all of them were in positions to create tailor-made institutions. The dataset allows us to identify those officers with the training and experience deemed necessary for a successful process of transplanting. A small number of interviews with surviving British officers conducted in 2016 provided a better understanding of this huge amount of data.
This article elaborates on this research agenda, which links the composition of the British colonial administrations in the mid-20th century with economic development, and presents the first findings taken from the biographical records of senior colonial officers. The next section introduces the theoretical concept of transplants and places the research agenda within the current economic debate on development.

\section{A Research Agenda around Transplants}

A study by Daniel Berkowitz, Katharina Pistor and Jean-Francois Richard on legal transplants serves as the starting point for our discussion. The authors, two of them economists and one a legal scholar, use an empirical model to argue that the practice of importing foreign law has been largely ineffective, unless the law is intentionally adapted to the local law or unless there was already an initial level of familiarity within the population. Whereas adaptation is an intentional process in which foreign law is re-written to fit into the local legal context, familiarity is very rare. It occurs when countries share a close common culture and legal history (e.g. Scandinavian countries). Without adaptation or familiarity, the legal transfer is unreceptive - an outcome which the authors call the transplant effect. It is characterized by dead written law, legal and political bodies and public agencies without legitimacy, and often high levels of corruption. ${ }^{20}$

Economists argue that weak legal institutions are detrimental to economic and social development. A study by two Argentinean economists on illegal squatters in the suburbs of Buenos Aires showed that those squatters who randomly received a legal title to their hitherto illegal dwelling substantially reorganized their lives. Over the course of twenty years these squatters invested in better health and housing. They reduced the size of their households and cared for the education of their children. The only difference between them and their luckless neighbors was a piece of paper granting them a legal title to their home and to the small piece of land on which it rested. ${ }^{21}$ Their neighbors without legal certainty dared not invest in their lives and home to the same extent. Institutional economists know that weak 
legal institutions are very persistent. Countries with weak institutions (such as dead law) can become locked into a development trajectory which determines their chances of development over decades or even centuries. ${ }^{22}$ This makes the question of how good institutions can be attained even more important.

The study by Berkowitz, Pistor and Richard has not been seminal in how economists or development practitioners think about development. In fact, transplants have been somewhat neglected in the ongoing academic debates on development. ${ }^{23}$ Established scholars have taken it as a given that transplants hardly ever work. ${ }^{24}$ In particular, the question of how transplants can be adapted to the legal context of the receiving society has never been settled.

The lack of academic interest in legal transplants is surprising, because a research program on transplants could not be more relevant. Institutional transplanting has been widely practiced over the last centuries. During industrialization, continental European countries aimed to reduce their relative economic backwardness towards the United Kingdom. ${ }^{25}$ Japan copied heavily from the West during the Meiji Restoration and itself exported institutions to Asian colonies a few decades later. ${ }^{26}$ More recently, the integration of Eastern European countries into the European Union included substantial legal and institutional harmonization in the new member states. ${ }^{27}$

Bureaucrats have been at the center of all these major attempts to transplant institutions. Their skills, their level of training and understanding of the transplanted law, are essential for the success or the failure of transplants. Economists call the body of knowledge, skills and personality of an individual, 'human capital. Development scholars consider human capital a central factor for long-run social and economic development. But more than 50 years after the term has been coined, the debate on exactly how human capital can increase developmental potential is still ongoing. ${ }^{28}$ Hence a research program investigating the role of senior bureaucrats also contributes to this ongoing debate on the role of human capital - quite apart from the discussion of institutional transplants.

The dozen or so Malawians destined to become the first lay magistrates of their country had probably little concern for such academic debates. They may have felt lucky that their instructor could run a crash course on substantial bodies of British law in the middle of Africa. From an academic perspective, the story is the beginning of new research program in which the decolonization of the British colonial empire provides the historical setting.

\section{Institutional reform and British decolonization}

Between 1947 and 1997, 50 British colonies and territories gained independence (see Table 1). The recruitment in 46 of them was organized via the Colonial office in London. ${ }^{29}$ This is important, because the Colonial Office maintained and updated the personnel records of these officers until 1966. At its peak in 1960, over 20,000 overseas officers were employed in higher public services across the territories. ${ }^{30}$ Anyone interested in institutional transplanting will want to investigate the years from roughly 1940 to the early 1970s, when the terms >development « and sgood government s swept through Whitehall and the Colonial Office and the colonies were prepared for self-government and, later, for independence.

\begin{tabular}{ll}
\hline 1947 & (India) \\
1948 & Ceylon, Palestine \\
1956 & (Anglo-Egrptian Sudan) \\
1957 & Gold Coast, Malaya \\
1960 & Cyprus, Nigeria, British Somaliland \\
1961 & Sierra Leone, Tanganyika \\
1962 & Jamaica, Trinidad and Tobago, Uganda \\
1963 & Kenya, Zanzibar, Sarawak, North Borneo \\
1964 & Malta, Nyasaland, Northern Rhodesia \\
1965 & Singapore, The Gambia, Maldives \\
1966 & British Guiana, Bechuanaland, Basutoland, Barbados \\
1967 & Aden \\
1968 & Mauritius, Swaziland \\
1970 & Fiji, Tonga \\
1973 & Bahamas \\
1974 & Grenada \\
1976 & Seychelles \\
1978 & Dominica, Solomon Lslands, Ellice Islands \\
1979 & St Vincent and the Grenadines, St Lucia, Gilbert Islands \\
1980 & (Southern Rhodesia), New Hebrides \\
1981 & British Honduras, Antigua \\
1983 & St Christopher (St Kitts) and Nevis, Brunei \\
1990 & (Namibia) \\
1997 & Hong Kong \\
\hline
\end{tabular}

Note: Countries in parentheses are included as markers in the chronology of independence in the British Empire. They were not staffed by the Colonial independente.

Table 1: British territories and their dates of independence, 1947-1997. Countries in parentheses were not staffed by the Colonial Office in London.

SOURCE Anthony Kirk-Greene: On Crown Service, London 1999, p. 81. 
With the onset of World War II, the pre-war vision of a dependent empire based on imperial trade and business interests changed radically. It was replaced by the concepts of >development and sgood government were based on the idea that social reform in its widest sense was necessary for the political education of the local population. The so-called Fabian Colonial Bureau was established in 1940 and became an influential forum for the elaboration of colonial policy. Labour won the general elections in 1945 and its colonial policies accepted the Fabian position that the >development ' of the colonies could not be left to market forces and industrial interests. The imperial state was needed to bring about social and economic improvements and prepare the colonies for self-government. This was seen as the best way to retain the empire intact for as long as possible. ${ }^{31}$ It was also seen as an answer to the growing importance of international organizations and their development professionals in the colonies. Between 1940 and 1960 these groups were still very small in number, but they became gradually more important than missionaries and bankers in shaping the debate and the policies. The International Labour Organization, for example, was an early advocate for labor legislation in the colonies. In this sense the United Nations and other development practitioners forced British officials more and more onto the international stage. ${ }^{32}$ With the beginning of the post-war period, the United States started an extensive bilateral aid program in Africa - outside the United Nations. Private American funds and interest groups were involved in the educational advancement of the African people. ${ }^{33}$

Maybe in response to these new players, the implementation of the new British development policy began with social welfare programs. The Colonial Welfare and Development Act of 1940, for example, established the principle that the British taxpayers had a duty to contribute to the development of the colonial peoples. This was a new doctrine which also added an extra dimension to the idea of good government. It was no longer enough for serving officers to uphold law and order and collect taxes. The new development philosophy gave colonial officers an active role in preparing the colonial subjects for participation in the political and industrial life of the territory.

Just like sdevelopment`, the term sgood government was rarely defined in detail. 'Good government s was not initially designed to diminish the position of British officers within the territorial administrations. It became popular among colonial officials partly because it implied that self-government meant less competent administration and thus justified a long period of British control. The various development and welfare schemes, however, were intended to build a political class capable of running the machinery of the state. Whenever the local elite would reach the same (British) standards of governance, the transfer of power could follow. ${ }^{34}$

Building the machinery of a state included more laws and institutions. These were closely modeled on what was considered good practice in the UK. The transplanting process itself can be imagined in a very concrete manner. Thousands of pages of legal text were drafted as colonies modeled their young democracies on the example of the British system. New departments and organizational units were created across colonies. They ranged from the departments and ministries to entities such as the National Lottery or the Tourism Bureau. ${ }^{35}$ A multitude of training courses prepared local civil servants for their careers in these new offices. If these structures and the organizational rules by which they worked were well adapted to local practices, there was a good chance of success. This was easier when, for example, an existing department within the former colonial administration was extended in size and functions, and local staff with professional experience in the colonial administration was placed in charge shortly before independence. Yet even in these cases, the incentives differed between the British officer handing over and his local successor.

Besides formalized structures, unwritten norms ways of doing things - were transplanted, and these processes where less straightforward. An example: We know today that a civil service based on the principles famously put forward by Max Weber matters for economic development. ${ }^{36}$ James Rauch, an economist, and Peter Evans, a sociologist, call this the /Weberian state hypothesis،. The authors argue that the replacement of rule based on patronage by a professional state bureaucracy is a necessary (though not sufficient) condition for long-term economic development. Among others, key institutional characteristics of what the authors call a Weberian bureaucracy include meritocratic recruitment as opposed to politically motivated appoint- 


\section{On Tour: handover and rural administration in British Africa}

Tours into the bush to keep in contact with Native Authorities were a core activity in a district officer's life. The relationship between local chiefs and the coIonial (later civil) district administrator governed tax collection, census activities or the delivery of justice in these areas. British district officers usually liked these stours', or they left the service. Many of them disliked the prospect of being transferred to a desk job in the capital. Unlike British officers many African civil servants who succeeded the British colleagues preferred urban employment to rural posts, which were considered backwaters and which provided fewer career opportunities. Ethnicity was a third factor. British officers were advantaged in being impartial to inter-ethnical tensions. In Malawi for example, these distinct personal incentives had a measurable impact once the handover to local Malawian district officers had been completed. The total number of district officers in rural posts declined gradually from 92 in 1960 to 77 in 1972 as local staff were reluctant to respond to the vacancies which became available when overseas staff left. At the same time the average length of service in this rank dropped from 7,2 years in 1960 to 4,4 years in 1970 .*

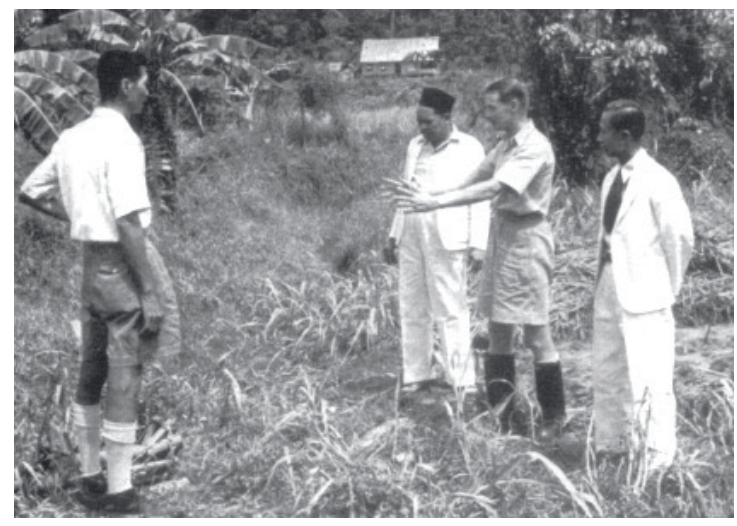

Photograph 1: District officer on tour in North Borneo

SOURCE Kirk-Greene, On Crown Service, p. 136.

* Lawley, "Achievements of the British Colonial Service«, p. 271; Kenneth Younger, The Public Service in the New States. A Study in Some Trained Manpower Problems, London 1960, p. 26; Selassie, The Executive in African Governments, p. 209; and Colin Baker, "The Administrative Service of Malawi - A Case Study in Africanisation «, in: The Journal of Modern African Studies 10 (1972), p. 543-560, here p. 552-553. ments, and procedures safeguarding the integrity of civil servants. ${ }^{37}$ The British themselves had integrated these principles into their public services roughly a century earlier, although that had been a more gradual process. ${ }^{38}$ The Colonial Office in London, for example, still recruited Administrative Service Officers using school education as an indicator for class. The system was clearly based on patronage and abandoned only in $1930 .{ }^{39}$ For reasons that have received little attention, the general level of corruption among colonial officers was surprisingly low. ${ }^{40}$ Transplanting Weberian principles or integrity and transparent appointments into the newly established public services, however, proved very difficult and often failed.

The fundamental problem may have been that Weberian principles were not necessarily compatible with local, patrimonial institutions shaping executive authority. The notions of integrity, corruption and political neutrality were doubtless known to individuals working inside the colonial administrations. However, the rules and processes safeguarding these standards may not have been recognizable as such. Moreover, they may have been considered overly burdensome to non-European staff. Without a prolonged time of working with the new regimes, their advantages would not become clear. This is the view of Amishadai Adu, who was one of the first Africans to enter the higher colonial service. A gifted administrator himself, Mr. Adu left his home civil service in Ghana and became an international consultant to the UN and to other colonies which aimed to reform their civil services in view of approaching independence. In 1965 he warned of overly complex structures, well-intended but hard to manage.
A danger, which presents itself to all new African states in greater or lesser measure according to the stages reached in their staff development pro- grammes, is that they may have inherited such com- plex standards of administrative and departmental structures and procedures, backed in some cases by statutory provisions, as to invite serious difficulties when they are staffed by local personnel who replace departing expatriate officers. ${ }^{41}$

The Public Service Commission (Civil Service Commission, or simply Commission) was such an imported de- 
partmental structure. It was an organizational unit in charge of all personnel-related issues, such as the appointments of civil servants. After 1945 the British established Public Service Commissions in each colony to guarantee the political neutrality of local civil servants and prevent nepotism. Initially, Commissions were created as advisory bodies to the governor. The British were fully aware that the Commission was a foreign transplant and likely to find little support with ministers and members of legislatures, who preferred to control who advances into powerful positions within the civil service. A handbook advised overseas officers on how a Public Service Commission could be best established in the colonies and which problems were likely to occur. ${ }^{42}$ As expected, the Commissions soon became unpopular with ministers and political leaders who had little control over the employment of their civil servants. Their members frequently suffered from political pressure and increasingly functioned as »the barrier to the politicization of the public service ${ }^{43}$ Before the British ceded full self-government, the Public Service Commission in each colony was given wide-ranging executive powers over all personnel matters below ministerial rank. It was an attempt to permanently install an organizational unit safeguarding the integrity and political neutrality of the future civil services. ${ }^{44}$ In hindsight we know that organizational units safeguarding transplanted law were no guarantee of success. After independence the Commissions' executive powers were downgraded to varying degrees across the new African states. The erosion of political neutrality and its adaptation to the political reality took different forms and occurred at different moments after independence. One way was requiring existing civil servants to join the (single) political party and influence their behavior via allegiance to the party. Another method was the appointment of politically loyal officers to positions outside the authority of the Commission..$^{45}$ Simple bullying of Commission members has also been reported by overseas officers who had remained in the service of independent Nigeria. ${ }^{46}$ Formal reform was another option. The local government reforms in Tanganyika of 1963 effectively politicized the district administrations. ${ }^{47}$ The example of the Public Service Commission boils down my argument on institutional transplants.

\begin{abstract}
These complex structures were usually imposed by the colonial administrations to ensure effective action without the responsible participation by the indigenous people. They are usually straight importations of structures which had proved workable or effective in the United Kingdom and which could work in Africa so long as there were British officers to man them. Elaborate systems have been set up in some or all of the states to control the use of land, the transport licensing system, immigration, the regulation of internal and external trade, to give only a few examples. In so far as new African Governments have adopted these systems wholesale - because in themselves they are good - and have endeavored to apply the policy of accelerated Africanization to them. There have been difficulties because of the falling off of standards. Where, however, there had been time to train and give experience to Africans before the expatriates left, the structures inherited have been real assets. ${ }^{48}$
\end{abstract}

\section{Her Majesty’s Overseas Service}

Not everyone in the colonial service was able to produce tailor-made institutional solutions on the basis of British originals. Can we specify exactly which biographical characteristics it takes for successful institutional adaptation? A research agenda with the aim to advance our knowledge on the role of civil servants in the transplanting process needs to collect detailed information on the education level, skills, and length of stay in the country of civil servants involved. The material is complemented with historical analysis of corresponding colonial records and interviews with surviving officers. This latter part is ongoing. ${ }^{49}$ The Colonial Office in London can be thanked for the former part. ${ }^{50}$ Like other international organizations, headquarters kept records of the biographical data of their senior personnel in the territories. The records of all colonial officers who served between 1939 and 1966 have been brought into digital form for the first time in 2015. ${ }^{51}$ The dataset contains the biographical information of over 14,000 officers, each with a minimum of ten years' service and each of them recruited by the Colonial Office in London, some of them with the help of Crown Agents. Table 2 gives an overview of the dataset. 


\begin{tabular}{ll}
\hline $\begin{array}{l}\text { Number of } \\
\text { records }\end{array}$ & 14,285 \\
\hline Time of service & $1939-1966$ \\
\hline $\begin{array}{l}\text { Territories } \\
\text { included }\end{array}$ & $\begin{array}{l}\text { All territories (colonies, protectorates) } \\
\text { which were under the administration } \\
\text { of the Colonial Office in London. This } \\
\text { excludes Dominions (New Zealand, } \\
\text { South Africa) and colonies with their } \\
\text { own colonial service (India, Sudan). See } \\
\text { Table 1 for a complete list. }\end{array}$ \\
\hline $\begin{array}{l}\text { Number of } \\
\text { territories }\end{array}$ & 46 \\
\hline
\end{tabular}

\begin{tabular}{ll}
$\begin{array}{l}\text { Conditions to } \\
\text { be listed in the } \\
\text { dataset }\end{array}$ & $\begin{array}{l}\text { All officers (British, local) who served on } \\
\text { pensionable terms between } 1939 \text { and } \\
1966 \text { and had a minimum of ten years } \\
\text { of service. These officers were recruited } \\
\text { by the Colonial Office in London. }\end{array}$ \\
\hline $\begin{array}{l}\text { Information } \\
\text { (mininum) }\end{array}$ & $\begin{array}{l}\text { Name, gender, date of birth, education, } \\
\text { entry year into the service, all } \\
\text { advancements until last position held. } \\
\text { Military service. }\end{array}$ \\
\hline $\begin{array}{l}\text { Information } \\
\text { (additional) }\end{array}$ & $\begin{array}{l}\text { Knighthoods and honors, language } \\
\text { skills, published books and articles, } \\
\text { participation at conferences, whether or } \\
\text { not the officer stayed on to serve in the } \\
\text { civil service of the independent country. }\end{array}$
\end{tabular}

Table 2: Characteristics of the dataset on overseas officers.

In the 20th century the colonial service was an international body of territorial services, which, from the mid1950s on, was charged with its own dissolution. Compared with a typical civil service in a European state today, a few features of colonial services are worth noting.

\section{Recruitment and employment}

While all members of the colonial service were servants of the Crown, they were employees of the territorial governments. Employment contracts were made between the colonial servant and the governor and paid out of the territorial budget. Only the recruitment of all administrative, managerial, supervisory, professional and senior technical grades was the responsibility of the Colonial Office in London with the help of the Crown Agents. Until held by overseas officers - British subjects or members of the Commonwealth (e.g. Canadians, South Africans). Higher posts offered a lifelong career with starting salaries around 600 British pounds per year in 1950 for a customs officer. This amounts to roughly 19,000 pounds in 2016 terms. ${ }^{52}$ Salaries varied slightly between regions and rose with seniority and rank. Towards the end of his career a >comptroller of customs could earn between 1,350 and 1,800 pounds (in 1950 values), subject to bonus payments and income tax which varied across colonies. ${ }^{53}$ The recruitment process allowed little room for negotiations as to where a recruit would be posted. After having received the telegram of acceptance, it was a take-it-orleave-it decision. The colonial service could not compete with a career in the British Foreign Service in terms of income and prestige, but offered very reasonable employment and career options for the more adventurous individuals. The local staff (before the 1950s mostly clerks, messengers etc.) were recruited directly in the colonies without interference from London. ${ }^{54}$ The system was quite entrenched. The first Africans to be appointed into higher grades were initially referred to 'Africans holding European posts.$^{55}$

\section{The budget}

Until 1957 (for Nigeria) and 1961 (for the rest of the colonies), Britain made no direct financial contribution to the personnel serving in the colonies. ${ }^{56}$ This naturally meant that poorer colonies had fewer financial possibilities and hence a smaller colonial administration compared to richer colonies. After 1945, however, very substantial funds were made available under the Colonial Development and Welfare Act and used for staff costs such as salaries. This benefited poorer territories such as Bechuanaland or Nyasaland. ${ }^{57}$

\section{The organization}

Overseas officers were organized in services which determined their career path and salaries. Teachers would be employed under conditions of the Education Service and doctors in the Medical Service - each with their own hierarchy, salary and ranks. The elite among these services was the Administrative Service, the members of which represented the governor in their colony and 
held (depending on the post and location) policy-setting, executive and quasi-judicial powers. ${ }^{58}$ These were generalists chosen from a specific social class in Britain, whose strength rested in their esprit de corps and in their high degree of flexibility. Speaking local languages was mandatory and years of service in remote rural posts (sthe tours`) were normal for young cadets and district officers before positions in the colonial secretariat, basically the government headed by the governor in the colonial capital, were considered. ${ }^{59}$ Administrative Service officers were naturally involved in the handover to local civil service before independence. Some remained in the civil service after independence. Colin Baker of Nyasaland remained in 1964 and served in the Malawi civil service in various positions until 1971. The high degree of localization within the Administrative Service meant that such officers were rarely transferred between colonies. More generally the whole colonial service was never really unified in the sense that a doctor from the Gold Coast Medical Service would help out in Sierra Leone or Kenya when needed.

\section{The numbers}

Because of the high degree of decentralization, the Colonial Office in London had strong documentation of the whereabouts of the overseas personnel but only a vague idea about the full size of the whole colonial service. In 1948, Charles Jeffries, then Deputy Under-Secretary of State for the Colonies, estimated the total size of the colonial service at about 300,000 , of which roughly 11,000 were overseas officers. ${ }^{60}$
Even before independence movements shook up colonial administrations, the structure of the colonial service underwent important changes after 1945. First, a surge of new recruits entered the colonial service after years of very low intake during World War 2 (WW2). Between June 1945 and the end of December 1953, a total of 11,357 new overseas officers came in. ${ }^{61}$ Particularly demobilized soldiers joined the colonial service. Nearly all new recruits of 1945 and 1946 had served with the armed forces. ${ }^{62}$ After 1951 the recruitment figures stabilized at a high level. In total the size of the higher colonial service almost doubled in less than ten years (see Figure 1). With independence still far away, all new recruits were offered a lifetime employment in the colonial service. Second, generous funds which had been made available under the Colonial Development and Welfare Act 1945 were set up to finance new development projects and fresh recruits. Unlike the recruits before 1945, the post-WW2 recruits also benefitted poorer colonies, who could now afford more personnel. ${ }^{63}$

\section{The 1950s and 1960s - preparing for independence}

The post-WW2 intake increased the size and functions of the secretariat in the colonial capital. With the expansion of economic and social activities, more functional departments were added in the colonial secretariat. Department heads reported to the governor through a financial secretary (or through a chief secretary) who - together with the department heads and the governor - sat in the legislative council and the executive council. Here, the policies and their implementation were decided.

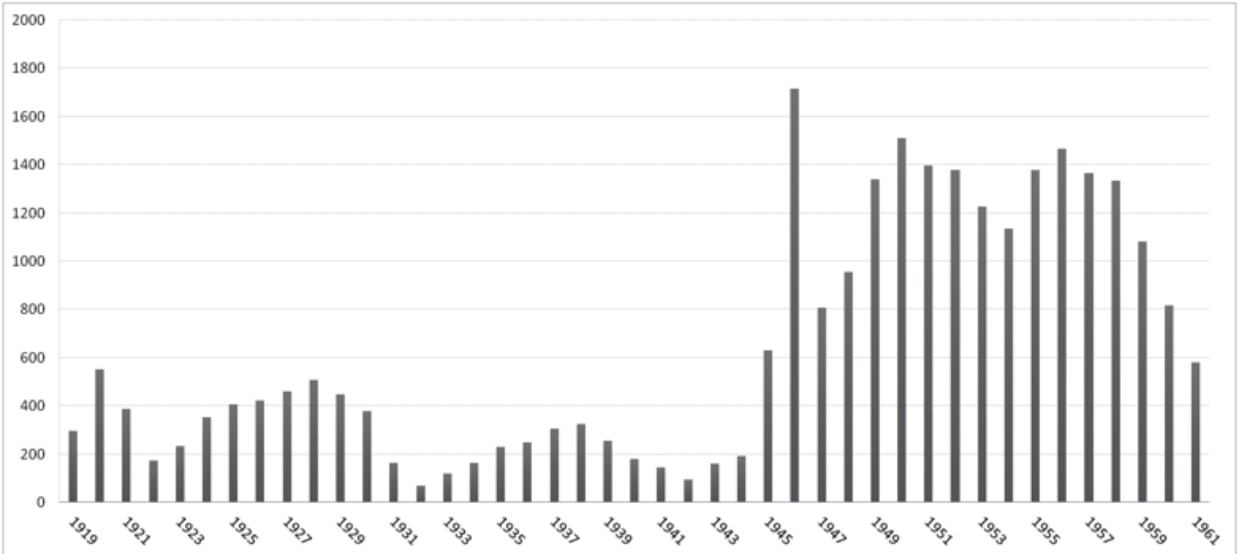

Figure 1: Recruitment of overseas officers per year 1919-1961.

SOURCES ODI, 1964: 25 and Colonial Office, 1962: 24 
In preparation for independence the departmental structure had to make place for a more democratic system. Around the time of the first elections the legislative council turned into a legislative assembly, which was in charge of setting policies. On the executive side the departmental organization in the colonial administration was replaced by a ministerial system with a cabinet co-ordinating the activities of the ministers. As independence drew closer, a typical ministry was staffed with both local and overseas servants and headed by a local minister advised and assisted by an overseas officer (usually from the Administrative Service) as his permanent secretary. ${ }^{64}$ It was during these crucial few years before independence that transplanting of British law and institutions took place.

How can we spot the tailors - those officers with the abilities to customize imported institutions in these crucial years before independence? From what we know about successful transplanting, the following conditions must be met: For a British-born officer, a tenure of at least five years in a single country seems reasonable proxy for understanding the local context. Additionally, the officer must have reached an executive grade in his or her career path (service) in the year of independence.

For a local officer, tenure in the country is only needed if the officer is employed outside the territory of his birth. To understand the functioning of the imported law he would need training abroad. I use a foreign diploma as a proxy for several years of studying abroad. Just like his British colleague, the officer must have reached an executive grade in his or her career path (service) in the year of independence.

Does a typical personnel sheet of a colonial officer provide this information? A simple query in the dataset that looked for police experts in Africa produces the personnel record of Mr. Robert Langley (among many others).

LANGLEY, M. R. D. O.B.E. (mil.) (1952), M.V.O. (1947), D., (1958), C.P.M. (1947).—b. 1913; ed. Glenwood High Sch., S.A., and Cape Town Univ.; Police offr. (cadet), Swaz., 1933 ; Bech. Prot., 1935; supt. of police, 1943; dep. comsnr. and ch. immig. offr., 1947; comsnr., police, 1949; asst. comsnr., Uga., 1955; senr. asst. comsnr., 1957; dep. comsnr., police, 1958; dep. inspr.-gen., pol., 1962; retd., apptd. O.S.R.B., 1963.
What can we learn from this record? Mr. Langley was born in 1913 and educated at the Glenwood High School in South Africa. We can assume he was a South African. The records never fully disclose the nationality. He joined the colonial police force in the protectorate of Swaziland in 1933 aged 20. Cadet is the entry rank for police officers. Two years on he was transferred to neighboring Bechuanaland Protectorate, where he reached the highest rank in the protectorate's small police force in 1947. The three tiny protectorates of Bechuanaland (today Botswana), Basutoland (today Lesotho) and Swaziland were administered by a High Commissioner in Cape Town, South Africa. It was common practice to exchange officers among them. What is a bit unusual is the fact that Robert Langley was not drafted for military service in World War II. Such an interruption of colonial service was very common among officers of his age group and would have been noted in the personnel record. Equally unusual is Mr. Langley's rapid career, which becomes evident once we compare his career path with colleagues from police forces in East Africa. Add to this his decorations: Order of the British Empire (OBE) in 1957, Member Victoria Order (MVO) 1947, and a colonial police medal in 1947. In 1949 he transferred to Uganda, a protectorate with a bigger colonial administration and a more substantial colonial police force. Compared with peaceful Bechuanaland, chances are Mr. Langley saw more action in Uganda, which had its share of riots in the late 1940s. In 1962, the year of Uganda's independence, Robert Langley retired as the deputy inspector general, the second highest post in the protectorate's colonial police. By then all British officers were offered a substantial payment for the loss of their career once the colony where they served gained independence. Robert Langley, aged 49, probably accepted the payment. His normal retirement age in East Africa would have been 55 years. ${ }^{65}$ This also explains that Mr. Langley started a new career in London with the Overseas Services Resettlement Bureau (OSRB) 1963. The OSRB had been founded in 1957 as a re-employment agency for colonial officers who had lost their position due to independence. Its services were free of charge and often relied on personal contacts of OSRB staff. Former police officers and prison guards were the second largest group of applicants in $1962 .{ }^{66}$ 


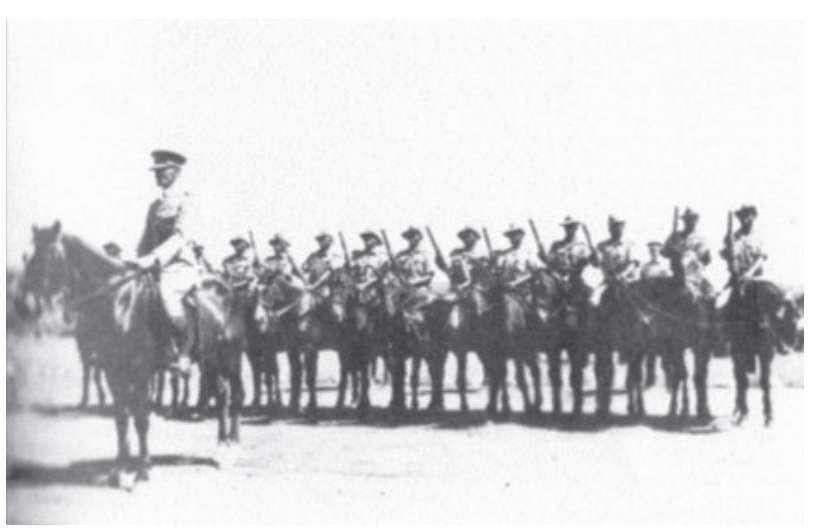

Photograph 2: Colonel Robert Langley (left) with a mounted police escort.

SOURCE Photograph by Noel Redman kindly made available by M.R.B. Williams. ${ }^{67}$

The information that we can extract from the data on Mr. Langley is substantial. The photograph above was kindly made available by a colleague of his, who I happened to interview in 2016. ${ }^{68} \mathrm{Mr}$. Langley's career in the colonial service was quite successful but it is otherwise typical for colonial officers serving in the mid-20th century. We have no written or oral account of Mr. Langley being a stailor`. It is very likely that he had enough local experience to judge where an imported institution would need adaptation if it concerned his line of career - say regulations governing police management in Uganda.

\section{Tailor-made transplants and development today}

How does this matter for economic development? Most economists today agree that tailor-made institutions are fundamental for long-term economic growth. It matters, for example, whether the property rights of homeowners are guaranteed by a law and whether it can be enforced at an efficiently working court. This is unlikely when the public servants working in the judiciary are not appointed based on their competence but on kinship. In a similar manner, poorly understood or poorly enforced traffic laws invite corruption (by police officers) and lead to avoidable loss of human lives. We know that such dysfunctional institutions tend to lock in and persist over decades if not centuries. Development scholars today use aggregate indicators like the Worldwide Governance Indicators to measure the quality of the srule of law in a given country, the reffectiveness of its government or the scontrol of corruption ‘ within public services. 'Government effectiveness`, for example, combines into a single group responses in questionnaires on the quality of public service provision and on the competence of civil servants, among others. Sources include organizations like Gallup, Afrobarometer or the Human Rights Database. ${ }^{69}$ Countries with higher scores of 'government effectiveness « rank higher in the Human Development Index. The causality may run both ways.

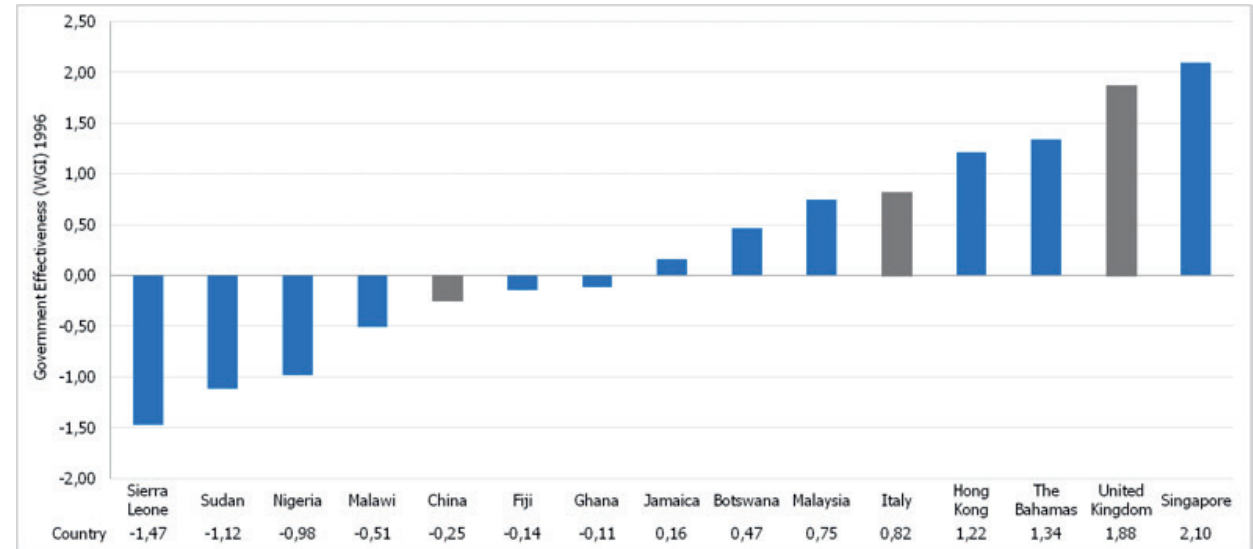

Figure 2: Government Effectiveness 1996 in former British colonies (in blue) and three non-colonies, selected countries.

SOURCE Worldwide Governance Indicators published in Kaufmann, Kraay, Mastruzzi, "Governance Matters VIII«. 
Richer countries can afford a better trained civil service. With this caveat in mind, governance indicators can serve as a rough gauge for the quality of a country's institutions and its development potential. Indeed the variation of institutions across former British colonies and - more generally - across the world, is remarkable. Figure 2 on the previous page shows the measures for 'government effectiveness in 1996 (the earliest available) for a number of former colonies plus China, Italy and the United Kingdom. The indicators assign scores to countries ranging from $+2,5$ (most effective government) to - 2,5 (worst score). We can see that the quality of civil services in former British colonies varies substantially from Sierra Leone to Singapore. Measures for the control of corruption or the rule of law (not pictured) display a very similar distribution. Legal and political scholars as well as economists have long sought to explain these differences across countries.

There is good reason to believe that colonial officers influenced this variation in government quality across the colonies. Figure 3 returns to a connection postulated by Mr. Adu earlier in this text.

Where, however, there had been time to train and give experience to Africans before the expatriates left, the structures inherited have been real assets. ${ }^{70}$
If $\mathrm{Mr}$. Adu is right, then colonies which retained a high number of colonial officers after independence were better at building local stailors - African civil servants with enough experience to tweak sinherited structures`. The information that we can deduce from the personnel records of nine African colonies alone lends support to Mr. Adu. Those colonies where colonial officers remained on after independence score substantially higher in terms of the effectiveness of their government.

The horizontal axis displays the number of years in which the share of overseas officers in the higher civil service remained between $75 \%$ and $25 \%$ for a number of African colonies at independence. The vertical axis measures government effectiveness in the year $1996 .{ }^{71}$ Botswana for example took over 14 years to reduce the share of overseas officers (British and African officers who had already served as colonial officers before independence) to a value of below $25 \%$. Sudan and Sierra Leone did that in less than four years. In Africa, where decolonization took only a matter of a few years (between 1957 and 1968), the graph shows a positive connection between the continued presence of overseas officers and the quality of future civil services. The longer former colonial officers were available after a country's independence, the more effective its government. In other words, a country which kept a high share of overseas

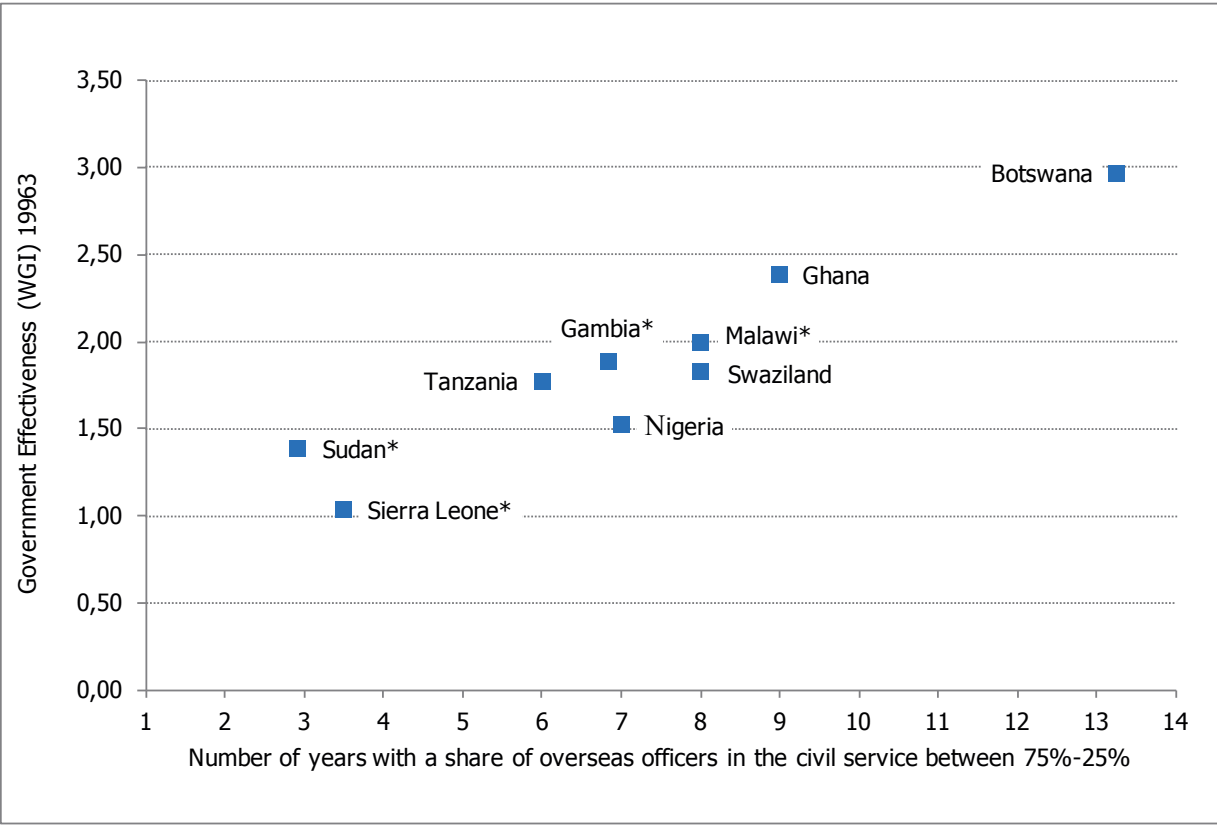

Figure 3: Government effectiveness in 1996 and duration of handover (in years) with a share of overseas officers between $\mathbf{7 5 \%}$ and $25 \%$.

* Administrative Service only. SOURCES Territorial staff lists and Worldwide Governance Indicators published in Kaufmann, Kraay, Mastruzzi »Governance Matters VIII«. 
officers in the administration for an extended period of time at independence had a more effective government in 1996. The ranking is reflected in the wealth of the countries. Botswana leads the group with roughly USD 15,800 GDP (PPP) per capita in 2016. Sierra Leone trails it with about USD 1,600 GDP (PPP) per capita. ${ }^{72}$

At this point in time we should take the findings with a pinch of salt. Because both the study of colonial files and conducting interviews are very time-intensive, only nine African colonies were included in the analysis by spring 2016. Given the small number of countries in this comparison, the findings can only be indicative. Then there is also the possibility that third factors may explain why colonial officers decided to remain in Botswana but retire early in others (e.g. Sudan). It is important that these factors do not also influence economic growth or the quality of the government in question. This can indeed be shown for each colony, but this will require the space and the format of another article - the second in this research agenda.

In conclusion, it hardly seems surprising that the length of time during which outgoing British officers were available to hand over the administration to their local successors matters for the quality of the civil services they left behind. Yet this finding is new. Until today, development scholars have been debating how various levels of government effectiveness in Africa can be explained. There are many related questions which are equally interesting from a scholarly point of view. Technically trained officers employed in the railroad services or in agriculture may have impacted, say, the industrial output of a former colony in a different manner from officers with backgrounds in law or economics. For how long do experts in these fields need to be posted in a given country to reach their full potential as institutional tailors? Modern development efforts today could benefit from such knowledge. Furthermore, the career paths of over 14,000 colonial officers provide a rich source of information for scholars interested in the history of administrations. To prepare the material for a more general historical analysis the biographical records will need to be complemented with other collected colonial material and with the personal accounts, i.e. interviews, of retired colonial officers. ${ }^{73}$ 
ACEMOGLU, Daron / J OHNSON, Simon / ROBINSON, James: "An African Success Story: Botswana", in: Dani Rodrik (Ed.), In Search of Prosperity. Analytic Narratives on Economic Growth, Princeton 2003, p. 80-119. A C EM O G L U, Daron / G A L LEGO, Francisco / ROBINSON, James: "Institutions, Human Capital and Development«, in: Annual Review of Economics 6 (2014), p. 875-912. A R M S T R O N G, Elia: "Integrity, Transparency and Accountability in Public Administration: Recent Trends, Regional and International Developments and Emerging Issues", in: United Nations, Department of Economic and Social Affairs (2005), p. 1-10. A D U , Amishadai: The Civil Service in New African States, London 1965. A L LE N, Douglas: The Institutional Revolution, Chicago 2012. B E R K O W I T Z, Daniel / P I S T O R, Katharina / R I C H A R D, Jean-Francois: „Economic Development, Legality, and the Transplant Effectu, in: European Economic Review 47 (2003), p. 165-195. B A K E R, Colin: »The Administrative Service of Malawi - A Case Study in Africanisation«, in: The Journal of Modern African Studies 10 (1972), p. 543-560. - Expatriate Experience of Life and Work in Nyasaland, vol. 5, Cardiff 2016 (forthcoming). B E C K E R, Gary: Human Capital. A Theoretical and Empirical Analysis with Special Reference to Education, Chicago 1964 [1993]. B U R K E , Fred: »Public Administration in Africa: The Legacy of Inherited Colonial Institutions «, in: Administration \& Society 1 (1969), p. 345-378. B U R R, Eric: Localization and Public Service Training. Oxford Development Records Project Report 4, Oxford 1985. CAMBODIA ROAD TRAFFIC ACCIDENT AND VICTIM INFORMATION SYSTEM: Annual Report 2004, Phnom Penh 2004. COLONIAL OFFICE: Appointments in His Majesty's Colonial Service, London 1950. - Colonial Overseas Service: monthly cumulative progress reports on vacancies filled from starting date of 1 June 1945, Reference: CO 1017/268, internal document released in 1984, London: The National Archives, 1953-1955. - The Public Service Commission in Overseas Territories, London 1962. E C K E R T, Andreas: Herrschen und Verwalten. Afrikanische Bürokraten, staatliche Ordnung und Politik in Tanzania. 1920-1970, Berlin, Boston 2016. FABIAN COLONIAL BUREAU: Cooperation in the Colonies, London 1945. F E H L I N G, Maya / N E L S O N, Brett / V E N KATAP U R A M , Sridhar: „Limitations of the Millennium Development Goals: a Literature Review«, in: Global Public Health 8 (2013), p. 1109-1122. F U R S E, Ralph: Aucuparius. Recollections of a Recruiting Officer, London 1962. G A L I A N I, Sebastian / S C H A R G R O D S KY, Ernesto: "Property rights for the poor: Effects of land titling", in: Journal of Public Economics 94 (2010), p. 700-729. G E R S C H E N K R O N , Alexander: Economic Backwardness in Historical Perspective - A Book of Essays, Cambridge 1962 [1966]. H E R B S T, Jeffrey: States and Power in Africa, Princeton 2014 (2000). H E R M A N S, Quill: »Towards budgetary independence: a review of Botswana's financial history, 1900-1973«, in: Botswana Notes and Records, 6 (1974), p. 89-115. H I L L, Joshua: The Agency Problem of the Empire. British Bureaucracy and Institutional Path Dependence, Unpublished Dissertation George Mason University, Fairfax Virginia 2007. H O D G S O N, Geoffrey: "What are Institutions?«, in: Journal of Economic Issues 40 (2006), p. 1-25. J E F F R I E S, Charles: Partners for Progress, London 1949. - Whitehall and the CoIonial Service: An Administrative Memoir 1939-1956, London 1972. KA U F M A N N, Daniel / KRAAY, Aart / MASTRUZZI, Massimo: "Governance Matters VIII: Aggregate and Individual Governance Indicators 1996-2008«, in: World Bank Policy Research Working Paper Series 4987 (2009). K E L E M E N , Paul:»Planning for Africa: The British Labour Party's Colonial Development Policy. 1920-1964«, in: Journal of Agrarian Change 7 (2007), p. 76-98. K I R K - G R E E N E , Anthony: On Crown Service, London 1999. - A Symbol of Authority. The British District Officer in Africa, New York 2006. K O H L I, Athul: State Directed Development, Cambridge 2004. L A N G E, Matthew: Lineages of Des- potism and Development, Chicago 2009. L A W L E Y, Jonathan: »Achievements of the British Colonial Service: A Retrospective View«, in: The Round Table 104 (2015), p. 267-280. L E E, John: Colonial Government and Good Government, Oxford 1967. M C G R E G O R, Sue: "Structural Adjustment Programmes and Human Well-being", in: International Journal of Consumer Studies 29 (2005), p. 170-180. M O R G A N , David: British Aid: Colonial Development. A Factual Survey of the Origins and History of British Aid to Developing Countries, London 1964. N O R T H, Douglass: Institutions, Institutional Change and Economic Performance, Cambridge (MA) 1990. N U N N , Nathan: "The Importance of History for Economic Development«, in: Annual Review of Economics 1 (2009), p. 65-92. O V E RE E M , Patrick: "The Value of the Dichotomy: Politics, Administration, and The Political Neutrality of Administrators", in: Administrative Theory \& Praxis 27 (2005), p. 311-329. P E J O V I C H, Svetozar: »Understanding the Transaction Costs of Transition. It's Culture, Stupid«, in: The Review of Austrian Economics 16 (2003), p. 347-361. PISTOR, Katharina / BERKOWITZ, Daniel: "Of Legal Transplants, Legal Irritants, and Economic Development«, in: Peter Cornelius, Bruce Kogut (Eds.), Corporate Governance and Capital Flows in Global Economy, New York 2003, p. 347-370. R A U C H , James / E V A N S, Peter: "Bureaucratic Structure and Bureaucratic Performance in Less Developed Countries«, in: Journal of Public Economics, 75 (2000), p. 49-71. R O D R I K, Dani, "Second-Best Institutions«, in: American Economic Review: Papers \& Proceedings 98 (2008), p. 100-104. - - / S U B R A MANIAN, Arvind / TREBBI, Francesco: "Institutions Rule: The Primacy of Institutions over Geography and Integration in Economic Development«, in: Journal of Economic Growth 9 (2004), p. 131-165. R WE Y E M A M U , Anthony: "Managing Planned Development: Tanzania's Experience«, in: Journal of Modern African Studies 4 (1966), p. 1-16. S E I D L E R, Valentin: „When Do Institutional Transfers Work? The Relation between Institutions, Culture and the Transplant Effect: the Case of Borno in North-eastern Nigeria«, in: Journal of Institutional Economics 10 (2014), p. 371-397. S E L A S S I E, Bereket: The Executive in African Governments, London 1974. S T O L P E R, Wolfgang: Inside Independent Nigeria. Diaries of Wolfgang Stolper. 1960-1962, Cornwall UK 2003. W E B E R, Max: Economy and society. An Outline of Interpretive Sociology, New York 1978. W E I N G A S T, Barry: "The Failure to Transplant Democracy, Markets, and the Rule of Law into the Developing World«, in: The Annual Proceedings of the Wealth and Well-being of Nations (2011), p. 29. W E S T N E Y, Eleanor D.: Imitation and Innovation: The Transfer of Western Organizational Patterns in Meiji Japan, Cambridge 1987 [1999]. W I L L I A M S , Peter: Technical Assistance. A Factual Survey of Britain's Aid to Overseas Development through Technical Assistance, London 1964. W I L L I A M S O N, Oliver: »The New Institutional Economics: Taking Stock, Looking Ahead«, in: Journal of Economic Literature 38 (2000), p. 596-613. W I N S T A N L E Y, George: Under Two Flags in Africa. Recollections of a British Administrator in the Bechuanaland Protectorate and Botswana in 1954 to 1972, Colchester 2000. WORLD COMMISSION ON ENVIRONMENT AND DEVELOPMENT: Our Common Future, Oxford 1987. Y O O, Dongwoo / S T E C K E L, Richard: „Property Rights and Economic Development: the Legacy of Japanese Colonial Institutions«, in: Journal of Institutional Economics, First View Article (2016), p. 1-28. Y O U N G E R, Kenneth: The Public Service in the New States. A Study in Some Trained Manpower Problems, London 1960. Z W E Y N E R T, Joachim: »Economic Culture and Transition«, in: Intereconomics 41 (2006), p. 182-188. 
1 Dr. Valentin Seidler is a member of the Ludwig Boltzmann Institute for Historical Social Science in Vienna. He is currently a visitor at the University of Warwick. The author is grateful for the financial support provided by the Austrian Science Fund (FWF) under an Erwin Schrödinger Programme (Grant \#J3848-G28).

2 See for example the information provided by the International Federation of Red Cross and Red Crescent Societies on capacity building. Online sourceifrc.org/en/what-we-do/capacity-building/.

3 In this text "development " is understood as economic development. Economic historians regard long-term economic growth as a necessary condition for human and social well-being. The most frequently quoted definition of "sustainable development " was published in the so-called Brundtland Report. It describes "... development that meets the needs of the present without compromising the ability of future generations to meet their own needs." World Commission on Environment and Development, Our Common Future, Oxford 1987.

4 Some entry points to this huge literature: Athul Kohli can serve as a starting point for the literature on colonial rule and development. Athul Kohli, State Directed Development, Cambridge 2004. Matthew Lange delivers a good account of direct and indirect rule in British colonies. Matthew Lange, Lineages of Despotism and Development, Chicago 2009. Jeffrey Herbst has recently published a revised version of his classic on African colonies. Jeffrey Herbst, States and Power in Africa, Princeton 2014 (2000). Finally, Selassie provides a very useful account from the point of an African bureaucrat. Bereket Selassie, The Executive in African Governments, London 1974. In the German literature the work of Andreas Eckert may serve as a first point of reference. Andreas Eckert, Herrschen und Verwalten. Afrikanische Bürokraten, staatliche Ordnung und Politik in Tanzania. 1920-1970, Berlin, Boston 2016.

5 Institutions are the humanly devised constraints that structure political, economic, and social interaction. They consist of both informal constraints (customs, traditions, and codes of conduct) and formal rules (e.g. contracts, the written law). Institutions are fundamental to the discipline of institutional economics. See Douglass North, Institutions, Institutional Change and Economic Performance, Cambridge (MA) 1990. A more recent discussion of institutions can be found in Geoffrey Hodgson, "What are Institutions?", in: Journal of Economic Issues 40 (2006), p. 1-25.

6 In 2004 an article published by Dani Rodrik, an economist at Harvard University, and co-authors more or less settled the debate that sound institutions are fundamental for economic growth. See Dani Rodrik, Arvind Subramanian, Francesco Trebbi, »Institutions Rule: The Primacy of Institutions over Geography and Integration in Economic Development«, in: Journal of Economic Growth 9 (2004), p. 131-165.

7 The research agenda presented in this text is based on a year of research at the Institute for Advanced Study in Princeton from 2014 to 2015 , where I was invited to develop an argument that links economic development, local bureaucrats and institutions. This is the first publication emerging from this year of study.

8 The 2030 Agenda for Sustainable Development is an international set of 169 development goals which is spearheaded by the United Nations. Online source sustainabledevelopment.un.org/sdgs.

9 See for example Sue McGregor, "Structural Adjustment Programmes and Human Well-being ", in: International Journal of Consumer Studies 29 (2005), p. 170-180. Critical literature on the UN Millennium Development Goals is reviewed in Maya Fehling, Brett Nelson, Sridhar Venkatapuram, "Limitations of the Millennium Development Goals: a Literature Review«, in: Global Public Health 8 (2013), p. 1109-1122.
10 See Dani Rodrik, "Second-Best Institutions«, in: American Economic Review: Papers \& Proceedings 98 (2008), p. 100-104, for a similar argument.

11 See Oliver Williamson, »The New Institutional Economics: Taking Stock, Looking Ahead «, in: Journal of Economic Literature 38 (2000), p. 596-613, here p. 597.

12 See Article 24 in the 1991 Law on Land Traffic and Article 22.3 in the 2007 Cambodian Land Traffic Law.

13 Katharina Pistor, Daniel Berkowitz, „Of Legal Transplants, Legal Irritants, and Economic Development«, in: Peter Cornelius, Bruce Kogut (Eds.), Corporate Governance and Capital Flows in Global Economy, New York 2003, p. 347-370.

14 See Joachim Zweynert, »Economic Culture and Transition«, in: Intereconomics 41 (2006), p. 182-188; and Valentin Seidler, "When Do Institutional Transfers Work? The Relation between Institutions, Culture and the Transplant Effect: the Case of Borno in North-eastern Nigeria«, in: Journal of Institutional Economics 10 (2014), p. 371-397.

15 Dani Rodrik forwards a very similar argument in Rodrik, "SecondBest Institutions«.

16 A working group in charge of finding recommendations to the shockingly high numbers of traffic casualties in Cambodia did not recommend such institutional adaptation. The authors do recommend the reform of the existing traffic law (dating from 1991) to include even more Western standards which will be hard to implement. The new Cambodian traffic law entered into force in 2007. See Cambodia Road Traffic Accident and Victim Information System, Annual Report 2004, Phnom Penh 2004.

17 US experts formed the largest group of foreign advisers in British colonies. Most of them came as researchers, educators or fieldworkers sponsored usually by the Social Science Research Council in New York, the Ford Foundation or the Fulbright Program. The diaries of Wolfgang Stolper who was sent as an economic advisor to Nigeria in 1960 give a colorful and frank assessment of the individuals who determined economic policies at that time. Although the numbers of non-British experts rose in the mid-1950s, they were rare in influential, policy setting positions before colonies reached independence. After independence however and more generally after the mid-1960s, foreign aid donors and their advisers created the multilateral and sometimes hard to coordinate landscape of advisers and experts. Coordinating among these new players (a task of UN and OECD) often overworked competent local officials. John Lee, Colonial Government and Good Government, Oxford 1967, p. 23-25, p. 250, p. 259-261. See also Wolfgang Stolper, Inside Independent Nigeria. Diaries of Wolfgang Stolper. 1960-1962, Cornwall UK 2003.

18 This account is taken from Colin Baker, Expatriate Experience of Life and Work in Nyasaland, vol. 5, Cardiff 2016 (forthcoming). The book is forthcoming in 2016.

19 Daron Acemoglu, Simon Johnson, James Robinson, "An African Success Story: Botswana«, in: Dani Rodrik (Ed.), In Search of Prosperity. Analytic Narratives on Economic Growth, Princeton 2003, p. 80-119.

20 See Daniel Berkowitz, Katharina Pistor, Jean-Francois Richard, „Economic Development, Legality, and the Transplant Effect», in: European Economic Review 47 (2003), p. 165-195.

21 See Sebastian Galiani, Ernesto Schargrodsky, "Property rights for the poor: Effects of land titling «, in: Journal of Public Economics 94 (2010), p. 700-729. The two authors, both economists, were initially looking for effects on the access to loans. They thought that the new property would be used to raise money and start a more productive business. While there were no or only modest effects on credit accessibility, the social factors (education, housing) were very strong.

22 Interestingly, informal norms (rules based on tradition or religion) 
are more persistent over time than the written law. See Peter Williams, Technical Assistance. A Factual Survey of Britain's Aid to Overseas Development through Technical Assistance, London 1964, p. 597. Institutional arrangements are specific to their historic context. For example, patronage in the British navy made sense as long as commanders could not be monitored when on the high seas. With better technology towards the end of the 19th century, this institution blocked the recruitment of most capable commanders. See Douglas Allen, The Institutional Revolution, Chicago 2012.

23 See Nathan Nunn, "The Importance of History for Economic Development«, in: Annual Review of Economics 1 (2009), p. 65-92, for a fine review of where the debate stood in 2009.

24 Barry Weingast, "The Failure to Transplant Democracy, Markets, and the Rule of Law into the Developing World«, in: The Annual Proceedings of the Wealth and Well-being of Nations (2011), p. 29.

25 See Alexander Gerschenkron, Economic Backwardness in Historical Perspective - A Book of Essays, Cambridge 1962 [1966].

26 See Eleanor D. Westney, Imitation and Innovation: The Transfer of Western Organizational Patterns in Meiji Japan, Cambridge 1987 [1999], for a splendid discussion on transplants during the Meiji Restoration in Japan. Dongwoo Yoo, Richard Steckel, „Property Rights and Economic Development: the Legacy of Japanese Colonial Institutions", in: Journal of Institutional Economics, First View Article (2016), p. 1-28, investigates how property right regimes were copied into Japanese colonies in Asia.

27 See for example Svetozar Pejovich, »Understanding the Transaction Costs of Transition. It's Culture, Stupid «, in: The Review of Austrian Economics 16 (2003), p. 347-361, who puts the conflict between imported law and informal practices (culture) in the center of the discussion.

28 The concept of human capital has been made popular by Gary Becker in 1964 (Gary Becker, Human Capital. A Theoretical and Empirical Analysis with Special Reference to Education, Chicago 1964 [1993]). See Daron Acemoglu, Francisco Gallego, James Robinson, »Institutions, Human Capital and Development", in: Annual Review of Economics 6 (2014), p. 875-912, for a recent contribution to the debate on how exactly human capital can deliver long run economic development.

29 Countries in parentheses were not staffed by the Colonial Service. Examples are India which had the Indian Civil Service or countries that were administered by the Dominions Office in London (Southern Rhodesia, Namibia). St. Kitts is another name for St. Christopher (hence the parentheses here) and was staffed with officers from the Colonial Service in London.

30 The figures are taken from Anthony Kirk-Greene, On Crown Service, London 1999, p. 74. Overseas officers were all officers (British, European or local) who had been recruited by the Colonial Office in London. These were predominately British subjects, but towards the end of the Empire, more local (African, Asian) citizens entered the ranks of "overseas" officers.

31 Paul Kelemen, „Planning for Africa: The British Labour Party's CoIonial Development Policy. 1920-1964«, in: Journal of Agrarian Change 7 (2007), p. 76-98, here p. 81; and the Fabian Colonial Bureau, Cooperation in the Colonies, London 1945.

32 See Lee, Colonial Government and Good Government, p. 28-29.

33 See Ibidem, p. 69.

34 See Ibidem, chapter 1

35 Jonathan Lawley, "Achievements of the British Colonial Service: A Retrospective View«, in: The Round Table 104 (2015), p. 267-280, here p. 275.

36 See Max Weber, Economy and society. An Outline of Interpretive Sociology, New York 1978.
37 See James Rauch, Peter Evans, "Bureaucratic Structure and Bureaucratic Performance in Less Developed Countries«, in: Journal of Public Economics, 75 (2000), p. 49-71; and Weber, Economy and Society.

38 See Allen, The Institutional Revolution where the institutional modernization of the Royal Navy or the Army, among others, in the early 19 th century are discussed.

39 Sir Ralph Furse was the main figure in charge of colonial recruitment. His autobiography gives a good account on the process and the attitudes behind it. See Ralph Furse, Aucuparius. Recollections of a Recruiting Officer, London 1962.

40 Joshua Hill, The Agency Problem of the Empire. British Bureaucracy and Institutional Path Dependence, Unpublished Dissertation George Mason University, Fairfax Virginia 2007.

41 Amishadai Adu, The Civil Service in New African States, London 1965, p. 116.

42 Colonial Office, The Public Service Commission in Overseas Territories, London 1962

43 Eric Burr, Localization and Public Service Training. Oxford Development Records Project Report 4, Oxford 1985, p. 117.

44 Political neutrality is understood as the political impartiality of civil servants. Under this concept public servants are not to engage in political activities which impair or seem to impair their ability to carry out the public duties in an impartial manner. Patrick Overeem, "The Value of the Dichotomy: Politics, Administration, and The Political Neutrality of Administrators«, in: Administrative Theory \& Praxis 27 (2005), p. 311-329, here p. 313. The term integrity in public administration refers to honesty or trustworthiness and is basically the antithesis to the terms corruption or abuse of office. Elia Armstrong, "Integrity, Transparency and Accountability in Public Administration: Recent Trends, Regional and International Developments and Emerging Issues«, in: United Nations, Department of Economic and Social Affairs (2005), p. 1-10, here p. 1.

45 Fred Burke, »Public Administration in Africa: The Legacy of Inherited Colonial Institutions«, in: Administration \& Society 1 (1969), p. 345378, here p. 352.

46 Burr, Localization and Public Service Training, p. 116.

47 Anthony Rweyemamu, »Managing Planned Development: Tanzania's Experience«, in: Journal of Modern African Studies 4 (1966), p. 1-16, here p. 8.

48 Adu, The Civil Service in New African States, p. 116.

49 The author is grateful for the support of the Ludwig Boltzmann Institute for Historical Social Study and the Austrian Science Fund (Erwin Schrödinger grant J3848-G28).

50 The Colonial Office published annual lists with information on the colonies and on the serving personnel. Colonial Office lists were published - with some interruptions during World War 2 - between 1939 and 1966.

51 The whole collection of biographical records has been brought into electronic form at the Institute for Advanced Study in Princeton upon the invitation of Prof. Dani Rodrik from 2014 to 2015. The project has been financed by Austrian Academy of Science and the Max Kade Foundation in New York.

52 The calculation is based on historical UK inflation rates (see http:// inflation.stephenmorley.org/).

53 Colonial Office, Appointments in His Majesty's Colonial Service, London 1950, p. $25 \mathrm{f}$.

54 Adu, The Civil Service in New African States, p. 130.

55 Ibidem, p. 18.

56 Williams, Technical Assistance, p. 23.

57 David Morgan, British Aid: Colonial Development. A Factual Survey 
of the Origins and History of British Aid to Developing Countries, London 1964, p. 58; Lee, Colonial Government and Good Government, p. 129; Quill Hermans, "Towards budgetary independence: a review of Botswana's financial history, 1900-1973«, in: Botswana Notes and Records, 6 (1974), p. 89-115, p. 106.

58 Colonial Office, Appointments in His Majesty's Colonial Service, p. 147.

59 Anthony Kirk-Greene, A Symbol of Authority. The British District Officer in Africa, New York 2006, p. 61.

60 Charles Jeffries, Partners for Progress, London 1949, p. 28.

61 See Colonial Office, Colonial Overseas Service: monthly cumulative progress reports on vacancies filled from starting date of 1 June 1945, Reference: CO 1017/268, internal document released in 1984, London 1953-1955.

62 Lee, Colonial Government and Good Government, p. 36.

63 Charles Jeffries, Whitehall and the Colonial Service: An Administrative Memoir 1939-1956, London 1972, p. 37.

64 Bereket Selassie, The Executive in African Governments, p. 190, p. 193.

65 Colonial Office, Appointments in His Majesty's Colonial Service, p. 83.

66 Kirk-Greene, On Crown Service, p. 105 f.

67 Coincidentally M. R. B. Williams, a former district officer of Bechuanaland remembered Mr. Langley (»Bob«) as a friend in an interview we conducted for another study. He was kind enough to send this photo of Mr. Langley. It has been published in George Winstanley, Under Two Flags in Africa. Recollections of a British Administrator in the Bechuanaland Protectorate and Botswana in 1954 to 1972, Colchester 2000.

68 Between January 2016 and June 2016 ten semi-structured interviews with former colonial officers in Africa were held. All interviewees were selected upon referral of the Overseas Service Pensioners' Association (OSPA). We are very thankful to OSPA for their invaluable help.

69 A full list of all sources and used to construct the indicators can be found in Daniel Kaufmann, Aart Kraay, Massimo Mastruzzi, "Governance Matters VIII: Aggregate and Individual Governance Indicators 1996-2008«, in: World Bank Policy Research Working Paper Series 4987 (2009). A caveat: Aggregate measures like the Governance Indicators are problematic for at least two reasons. First, the measures are interrelated. A country with a strong rule of law is also likely to have an effective government. Second, the indicators measure how close a country comes to an ideal standard of, say, how quickly a lawsuit can be resolved. A country with a legal tradition distinct from a global standard may still deliver a fair public service in the mind of its citizens which is not necessarily reflected in the indicator. With these shortcoming in mind, the Worldwide Governance Indicators appear strongly correlated with measures of human well being and development.

70 Adu, The Civil Service in New African States, p. 116.

71 The values have been increased by +2.5 to make a nicer reading on the chart. Hence the range of the indicator lies between 0 (worst possible) to +5 (best score)

72 These figures are corrected for purchase power parity (PPP) and are taken from the World bank 2016 online data http://data.worldbank. org/indicator/NY.GDP.PCAP.PP.CD.

73 I am grateful for the tremendous help of the Overseas Service Pensioners' Association (OSPA) and there members for their time and support. 


\section{Abstract}

The article presents a new research agenda which links the composition of the British colonial administrations in the mid-20th century with the economic development of former colonies. It presents the first findings taken from the biographical records of over 14,000 senior colonial officers which served in 46 colonies between 1939 and 1966. Legal transplanting, i.e. the process of copying foreign law into countries lacking them, is discussed as a common practice in international development efforts and as new approach in understanding long-term economic development. The approach puts emphasis on the senior bureaucrats who are in charge of institutional copying. Successful transplanting requires very specific training and personal experience in the receiving society. Colonial officers with such characteristics served in the British colonial administrations while decolonization provides a historic period of intensified legal and institutional transplanting.

\section{About the Author}

Dr. Valentin Seidler is a member of the Ludwig Boltzmann Institute for Historical Social Science in Vienna. He is currently a visitor at the University of Warwick. The author is grateful for the financial support provided by the Austrian Science Fund (FWF) under an Erwin Schrödinger Programme (Grant \#J3848-G28). 